\title{
THE RIGHT TO SOCIAL SECURITY IN THE PORTUGUESE CONSTITUTION
}

\begin{abstract}
Even though Portugal is a State-supported on social principles, a crisis environment can endanger some fundamental rights. This way, the Constitution could be at risk since social rights have highcost maintenance.

During the recent Portuguese crisis, several rights were affected according to the measures imposed by Troika. Nevertheless, the Portuguese Constitutional Court provided critical protection.

Taking into account this context, the author aims to evaluate the need to rethink the future of some rights that are taken for granted in Social States.

Słowa kluczowe: zabezpieczenie społeczne, prawo portugalskie, kryzys ekonomiczny, konstytucja

Key words: social security, Portuguese law, economic crisis, constitution

\section{Introduction}

Portugal is a State-supported on social principles since the 1976's Constitution, which emerged from the Revolution of $1974^{1}$. In fact, the Portuguese system is supported in the solidarity between all citizens, promoting the general and universal right to social security. This way, the Portuguese Constitution declares the global right to social security in its own text. In particular, the article no. 63, which supports the base of Portuguese social security and solidarity system, states the following: ${ }^{2}$
\end{abstract}

1 Apeles A. da Conceição identifies the evolution of the Portuguese Social Security legal system by remembering us the evolution from 1886 with the social goals provided by Decret of 17 July to the present Code of Contribution Regimes of the Social Security and Pension System - Law no. 110/2009, in force since January 2011 (see Segurança Social, $9^{\text {th }}$ ed. Almedina 2014, p. 49-62).

${ }^{2}$ As we will see in present work, this is not the only article of the Portuguese Constitution that should be mentioned regarding social security subjects. In fact, we should mention other important articles such as the following: article no. 8 (about international law); article no. 9/1 d (about the fundamental tasks of the State); article 59 no. (about the rights of workers); article no. 64 (about health protection); 
"1. Everyone has the right to social security. ${ }^{3}$

2. The state is charged with organising, coordinating and subsidising a unified and decentralised social security system, with the participation of the trade unions, other organisations that represent workers and associations that represent the other beneficiaries. ${ }^{4}$

3. The social security system shall protect citizens in illness and old age and when they are disabled, widowed or orphaned, as well as when they are unemployed or in any other situation that entails a lack of or reduction in means of subsistence or the ability to work. ${ }^{5}$

4. All periods of work shall, as laid down by law, contribute to the calculation of old age and disability pensions, regardless of the sector of activity in which they were performed. ${ }^{6}$

5. With a view to the pursuit of the social solidarity objectives that are particularly enshrined in this Article and in Articles 67(2)(b), 69, 70(1)(e), 71 and 72, the state shall, as laid down by law, support and inspect the activities and modus operandi of private charitable institutions and other not-for-profit institutions that are recognised to be in the public interest"7,8

This article shows a particular concern from the Portuguese constitutional lawmaker about the protection against social risks for all members of the community. ${ }^{9}$ For this reason, Portugal is, without any doubt, a "social state" that provides general social protection to all citizens is less fortuned times.

With the present contribution for the ILO Global Study: The Right to Social Security in the Constitutions of the World: Broadening the moral and legal space for social justice, we wish to debate social security from the particular context of the Portuguese Constitution and try to understand why the Portuguese Constitutional Court was a key defender of social rights in a time of crisis as the one that occurred from 2009 to 2014. This way, we will start to explore the Social Security environment provided by the Portuguese Constitution, and then our contribution will focus on the crisis issues and the attempts to endanger social rights and standards.

article no. 67 (about family protection); article no. 68 (about motherhood and fatherhood; article no. 69 (about childhood); article 70 (about youth); article 71 (about disabled citizens); article 72 no. (about the elderly); and article no. 81 (about the primary duties of the State). We will return to some of these articles further in this contribution.

3 The presente version came from the original one published in 1976.

${ }_{4}^{4}$ This is the text provided by the revision of 1982. The presente version's major difference from the original one is based on the wider number of representatives that must be part in the activity of social security.

${ }^{5}$ Results from the revision of 1997 when gave autonomy for the protection of disability.

${ }^{6}$ Version provided by the constitutional revision of 1997.

7 The presente version was in force by the 1997 constitutional revision.

8 This translation was provided by the Portuguese Constitutional Court's webpage that can be accessible in http://www.tribunalconstitucional.pt/tc/conteudo/files/constituicaoingles.pdf (accessed: 24.09.2018).

${ }^{9}$ Please see J.M. Sérvulo Correia in Teoria da Segurança Social, Lisbon 1965-1966, p. 34 (before the 1976's Constitution) and J. Miranda, R. Medeiros in Constituição Portuguesa Anotada, Vol. I, Coimbra 2005, p. 633-634. 


\section{The constitutional guarantees of social security rights}

As commonly defended by the Portuguese doctrine, ${ }^{10}$ there is an important division in the Constitution between two fundamental rights: (i) economic, social and cultural rights; ${ }^{11}$ and (ii) citizen's rights, freedoms and guarantees. ${ }^{12}$ This is the starting point to embrace the concept of social rights.

In one hand, citizen's rights, freedoms and guarantees are identified as "freedom rights". Jorge Miranda suggests that these rights are the citizen's protection against other powers from the State, ${ }^{13}$ while José Vieira de Andrade defends that the rights are perfectly determined by the Constitution and do not need any further intervention of the ordinary Portuguese lawmakers. ${ }^{14}$ On the other hand, the economic, social and cultural rights include the social rights. According to Jorge Miranda, these are rights of liberation from need, since they organise the solidarity of a community. ${ }^{15}$ José Vieira de Andrade reminds us that social rights need to be determined by the ordinary lawmakers. ${ }^{16}$ This way, we must bear in mind that social rights are always depending on the reality achieved by the infra-constitutional rules that are adapted to the daily reality of a concrete society.

Regarding citizen's social rights, Reis Novais supports the idea that should be included as regular fundamental rights with its common protection, since they promote the constitutionally protected ability of citizens to demand public actions from the State. ${ }^{17}$ In reality, this is a major concern that we will need further in the present work.

However, social rights are still a wide concept that need some densification. For example, the constitutional environment provides the distinction between the right to social security and the right to health. In fact, as pointed out by Jorge Miranda and Rui Medeiros, the social security system only protects health through the payment of sickness benefits. ${ }^{18}$ This implies one specific organization of the social security system

${ }^{10}$ For a more complexe development of these subject in Portuguese, please see J. Miranda, Manual de Direito Constitucional, Vol. IV, $5^{\text {th }}$ ed., Coimbra 2012; J. Vieira de Andrade, Os Direitos Fundamentais na Constituição Portuguesa de 1976, $2^{\text {nd }}$ ed., Almedina 2001; J. de Melo Alexandrino, Direitos Fundamentais - Introdução Geral, Principia 2007; C. Santos Botelho, 40 Anos De Direitos Sociais - Uma Reflexão Sobre O Papel Dos Direitos Fundamentais Sociais No Século XXI [40 Years of Fundamental Social Rights - A Reflection on the Role of Fundamental Social Rights in the 21st Century], Julgar 2016, 29, p. 197216, available at SSRN: https://ssrn.com/abstract=2912278 (accessed: 24.09.2018). In Spanish, we can also consult the work of the Portuguese author D. Carvalho Martins in: Enseñanzas de la experiencia portuguesa, Compatibilidad de prestaciones de Seguridad Social con Trabajo - directed by Carmen Sanchez Trigueros, Aranzadi 2016.

${ }^{11}$ See articles no. 58 to 70 of the Portuguese Constitution.

${ }_{12}$ See articles no. 24 to 57 of the Portuguese Constitution.

${ }^{13}$ See J. Miranda, Manual de Direito Constitucional, Vol. IV, $5^{\text {th }}$ ed., Coimbra 2012, p. 101-110.

${ }^{14}$ See ibidem, p. 182-191.

15 See ibidem., p. 101-110.

${ }^{16}$ See ibidem., p. 182-191. This author suggests that social rights constitute a citizen's asset against the State.

${ }^{17}$ See ibidem, p. 9-10.

18 See J. Miranda, R. Medeiros, Constituição..., p. 634. 
that assures mainly the protection needed by all citizens regardless of their position of worker. This way, the system as whole should offer protection for citizens in need by breaking up with the labour conception of social security. The right to social security is for all and, therefore, universal. ${ }^{19}$

One of major concerns on social security rules provided by the Constitution is the lack of direct effectiveness due to the need of embodiment through ordinary law. Most rules provided by the Constitution do not have any direct application on citizen's daily life. However, it's being accepted that, in some particular cases, social rights have similar structures to citizen's rights, freedoms and guarantee. ${ }^{20}$ This way, social rights may have some minimum application directly to citizens. For example, the Constitutional Court decided in $2002^{21}$ that the right to live in decent minimum conditions could be directly applied. Furthermore, the complexity of the right to social security includes quite different realities. For example, Jorge Miranda and Rui Medeiros recall the right of full use of all working career ${ }^{22}$ as a right perfectly densified and with a structure similar to citizen's rights, freedoms and guarantees. ${ }^{23}$

\section{The scope of the material and personal social security rights guaranteed by the Constitution}

According to the article no. 9/d of Portuguese Constitution, one of the fundamental tasks of the State is "to promote the people's well-being and quality of life and real equality between the Portuguese, as well as the effective implementation of economic, social, cultural and environmental rights by means of the transformation and modernisation of economic and social structures". As pointed out by Jorge Miranda and Rui Medeiros, these goals depend on the reality in order to be obtained. ${ }^{24}$

The worker's rights provided by the Portuguese Constitution are stated in article no. 59. So, in Portugal every worker as the right to "material assistance when he involuntarily finds himself in a situation of unemployment". ${ }^{25}$ This assistance in the context of unemployment binds workers from the public and from the private sector and includes other situations, such as the inability to work due to health problems. ${ }^{26}$

${ }_{19}$ By universal, we should not understand that social rights are for all citizens, but for citizens in need and in respect of the principle of equal treatment. So, it should depend on the legal framework in force. Also, it accepts that the right to social security is not incompatible with a professional based legal regime (see J. Vieira de Andrade, O Direito ao mínimo de existência condigna, Jurisprudência Constitucional 2004, 1, p. 26 and J. Miranda, R. Medeiros, Constituição...., p. 635-637).

${ }^{20}$ See J. Miranda, R. Medeiros, Constituição..., p. 634.

${ }^{21}$ Judgement no. 509/02.

${ }^{22}$ See article no. 63/4 of the Constitution.

${ }^{23}$ See J. Miranda, R. Medeiros, Constituição..., p. 634 and judgement no. 411/99.

${ }^{24}$ See ibidem, p. 101.

${ }^{25}$ See article no. 59/1, e) of the Portuguese Constitution.

${ }^{26}$ See J. Miranda, R. Medeiros, Constituição..., p. 609. 
Also, the State is in charge to ensure the protection of the work done by women during pregnancy and following childbirth. ${ }^{27}$

Regarding health, ${ }^{28}$ the Portuguese Constitution states that "everyone has the right to the protection of health and the duty to defend and promote health". ${ }^{29}$ Also, "the right to the protection of health shall be fulfilled by means of a universal and general national health service which, with particular regard to the economic and social conditions of the citizens who use it, shall tend to be free of charge" ${ }^{30}$ In general terms, this health system is supported by monthly contributions provided by all the workers ${ }^{31}$ and employers. ${ }^{32}$ Still, the right to public health is for all citizens regardless their professional status. ${ }^{33}$ Nevertheless, the right to health protection do not benefit from the citizen's rights, freedoms and guarantees regime, so it cannot be claimed directly by citizens. ${ }^{34} \mathrm{~A}$ different theme is the protection provided by the social security system to workers that are not able to work in a temporary basis. ${ }^{35}$ This right is exclusive to workers with a minimum period of 6 months' contributions. ${ }^{36}$

The family protection is also provided by the Portuguese social system. As a matter of fact, the Constitution's article no. 67 express that "as a fundamental element in society, the family has the right to protection by society and the state and to the effective implementation of all the conditions needed to enable family members to achieve personal fulfilment". ${ }^{37}$ The protection provided by society and the state has many forms, such as the promotion of social and economic independence of households, the access of a national network of crèches and other social facilities, cooperating with parents in relation with their children education, regulating taxes and social benefits in harmony

27 See article no. 59/2, c) of the Portuguese Constitution. Jorge Miranda and Rui Medeiros remind us that this right illustrates the dimension of the principle of equality by giving a special protection during pregnancy and childbirth (See J. Miranda, R. Medeiros, Constituição..., p. 613).

${ }^{28}$ Catarina Santos Botelho states that the right to health needs a logistic and establishment of rules in order to ensure an effective interpretation and enforcement (see C. Santos Botelho, Os direitos sociais num contexto de austeridade: um elogio fúnebre ao princípio da proibição do retrocesso social? [Social Rights in a Context of Austerity: An Eulogy to the Principle of the Prohibition of Social Retrogression?], Revista da Ordem dos Advogados 2015, I/II, p. 259-294. Available at SSRN: https://ssrn.com/abstract=2911142 (accessed: 24.09.2018).

${ }^{29}$ See article no. 64/1 of the Portuguese Constitution.

${ }^{30}$ See article no. 64/2 of the Portuguese Constitution.

${ }^{31}$ The monthly payment of contributions by workers, in general terms, is different for independent and dependent workers. Traditionally, it's more demanding the contribution for independent workers, however, if these workers have more than $90 \%$ of their activity for the same contractor, the company must contribute with $5 \%$.

${ }^{32}$ Regarding dependent workers, the common contribution for the social security system it's of $34,75 \%$ calculated from the salary. Nevertheless, only $11 \%$ are owed by the worker and $23,75 \%$ by the employer.

${ }^{33}$ Even the foreigners and stateless citizens according to article no. 15/1 of the Constitution and Jorge Miranda and Rui Medeiros (see Constituição..., p. 654).

${ }^{34}$ This way, see J. Miranda, R. Medeiros, Constituição..., p. 653.

${ }^{35}$ Protection through sickness benefits.

${ }^{36}$ See article no. 9 of Decree-Law no. 28/2014 of 4 February.

37 See article no. 67/1 of the Portuguese Constitution. 
with family costs, promoting the reconciliation of work and family life, among others. ${ }^{38}$ Subsequently, in accordance with this family's protection, it's important the underline the extension of this constitutional right to motherhood and fatherhood. In fact, according to Portuguese Constitution, "fathers and mothers have the right to protection by society and the state, together with the guarantee of their own professional fulfilment and participation in civic life" ${ }^{39}$ So, motherhood and fatherhood is assumed, without any doubt, as an eminent social value..$^{40}$ By this reason is ensured directly by the Constitution not only the women's right to special protection during pregnancy and after childbirth, but also the right to an adequate period of leave from work without loss of remuneration or any privileges. ${ }^{41}$ Likewise, fathers are entitled to an acceptable period of leave from work, in accordance with the interests of the child and the needs of the household. ${ }^{42}$ The period of leave has an important impact in both labour market and social security, since it provides the right of absence from work and entitlement to benefits provided by the social system. ${ }^{43}$

Similar to family's protection given by the Constitution are the rights of childhood. Here the Constitution declares the state and society as promoters of the protection from abandonment, discrimination and oppression and from the improper exercise of authority in the family or any other institution. ${ }^{44}$ Thus, also the youth is protected in order to ensure the effective fulfilment of their economic, social and cultural rights by having access to a particular protection, for example, in a context of a first job, work and social security. ${ }^{45}$

The Constitution also establishes full protection to disable citizens. Moreover, it provides that the state shall implement a national policy (i) for the prevention of disability and the treatment, rehabilitation and integration of disabled citizens and the provision of support to their families, (ii) to educate society in such a way as to make it aware of the duties of respect and solidarity towards them, and (iii) to undertake the charge

${ }^{38}$ See article no. $67 / 2$ of the Portuguese Constitution.

39 See article no. 68/1 of the Portuguese Constitution.

40 See article no. 68/2 of the Portuguese Constitution.

${ }^{41}$ See article no. $68 / 3$ of the Portuguese Constitution.

${ }^{42}$ See article no. 68/4 of the Portuguese Constitution. Here the same right is ensured to both mothers and fathers. Nevertheless, these rights must be achieved through the ordinary laws that defines, for example, the period of time that each parent can benefit from. In Portugal, these rules are included in the Labour Code.

43 Since the Labour Code reform of 2009, the right of leave after the childbirth is no longer exclusive of women. In fact, now it's the right of a working parent regardless the gender. Of course, for many reasons, in case of silence there is a presumption that the "maternity" leave will be used by the mother, however both working parents can choose to share this leave. Still, the mother is forced to exercise the right of "maternity" leave for the first 6 weeks after the childbirth by obvious recovery reasons.

44 See article no. 69 of the Portuguese Constitution.

45 See article no. 70/1, b) of the Portuguese Constitution. 
of ensuring that their rights are effectively fulfilled, without prejudice to the rights and duties of their parents or guardians. ${ }^{46}$

On the other hand, the elderly are protected by the Constitution in many general aspects. However, it's stimulated that the "policy for the elderly shall include measures of an economic, social and cultural nature that tend to provide elderly persons with opportunities for personal fulfilment by means of an active participation in community life". ${ }^{47}$ The ordinary lawmaker provides in particular this goal through the retirement system and other policies, that, as we will see, were the reality more affected during the crisis.

Finally, the Constitution defines some of the priority duties of the state. For the present contribution, it's fundamental to point out the following key duties:

a) within the overall framework of a sustainable development strategy, promote an increase in people's social and economic well-being and quality of life, especially those of the most disadvantaged persons; ${ }^{48}$

b) promote social justice, ensure equal opportunities and carry out the necessary corrections to inequalities in the distribution of wealth and income, particularly by means of the fiscal policy; ${ }^{49}$

c) create the legal and technical instruments needed to democratically plan economic and social development. ${ }^{50}$

\section{Threats to social security rights in times of economic crisis}

One of Portuguese major concerns regarding social security in times of economic crisis is the decrease of social rights. The debate urged in these situations usually turns into a huge generation conflict, since the future of the community is supposed to depend on the decline of former generations rights or the opposite. This is the easiest solution for the present difficulties. However, the problem is that to maintain the present rights, most of the times the future rights are reduced for younger generations. Therefore, we have a generation conflict of young citizens against older citizens and vice-versa. So, this is usually the base of the discussion in countries trying to emerge from severe economic crisis and not only in Portugal.

Protecting the rights acquired by older generations versus protecting the expectations of younger generations were, this way, one of the main focus of debate in Portugal. The other was the eternal discussion between public and private sector.

46 See article no. $71 / 2$ of the Portuguese Constitution.

47 See article no. 72/2 of the Portuguese Constitution.

48 See article no. 81, a) of the Portuguese Constitution.

49 See article no. 81, b) of the Portuguese Constitution.

50 See article no. 81, j) of the Portuguese Constitution. 
Since 2009, Portugal was submerged in period of severe crisis. ${ }^{51}$ The economic and finance context was in such a way that the country needed the intervention of external entities with a conditioned period of sovereignty from 2011 to $2014 .{ }^{52} \mathrm{In}$ order the secure economic support, Portugal signed a Memorandum of Understanding (MoU) with the members of Troika - European Commission, European Central Bank and International Monetary Fund - with several settings which the help was support on. This agreement promoted a European Financial Stabilization Mechanism supported by the Council Regulation no. 407/2010 of 11 of May 2010.53 David Carvalho Martins remind us that the normative effect of the MoU is debatable; nevertheless, we must accept its influence in the changes on the Portuguese Labour Code and social security legal framework..$^{54}$ The original version of the MoU received several revisions from 2011 to 2013 with intensification on the changes imposed by Troika. ${ }^{55}$ Nevertheless, the implementation of new rules regarding the labour and social security issues were depending on the consultation of the social partners. ${ }^{56}$

It's also important to point out that the MoU had the goal of (i) reducing the Government deficit to below 10,068 million euros (equivalent to 5.9\% of GDP based on current projections) in 2011, 7,645 million euros (4.5\% of GDP) in 2012 and 5,224 million euros (3.0\% of GDP) in 2013 by means of high-quality permanent measures and minimising the impact of consolidation on vulnerable groups; (ii) bringing the

51 This crisis affected differently other countries such as Spain, Ireland and, in particular, Greece. However, other countries felt also the effects of this crisis, but without any external intervention. In Portugal, the labour market competitiveness was considered one of the major centres of intervention in order to ensure a reaction to the crisis environment. The Council of Ministers Resolution no. 101B/2010 of 27 of December provided the so-called Initiative for Competitiveness and Employment where were stablished several measures in different areas, including for the Portuguese labour market (for more details about this subject regarding Labour Law in particular, please see D. Carvalho Martins, Labour Law in Portugal between 2011 and 2014, Labour Law and Social Security Law at the Crossroads - Focused on International Labour Law Standards and Social Reforms, M. Stefko (ed.), Charles University in Prague, Faculty of Law, 2016, p. 217-219).

${ }^{52}$ David Carvalho Martins identifies this period as "the years of the troika" (see D. Carvalho Martins, Labour Law in Portugal..., p. 70).

53 We must remind that Eurogroup and ECOFIN Ministers issued a statement in $8^{\text {th }}$ April of 2011 clarifying that EU and euro-area financial support would be provided on the basis of a policy programme supported by strict conditionality and negotiated with the Portuguese authorities, duly involving the main political parties, by the Commission in liaison with the ECB, and the IMF. Also, further to the EU support from the European Financial Stabilization Mechanism, loans from the European Financial Stability Facility contributed to the financial assistance. The Loan Facility Agreement on the European Financial Stability Facility financing contribution specified that the disbursements there under are subject to the compliance with the conditions of the MoU.

54 See D. Carvalho Martins, Labour Law in Portugal..., p. 70.

55 The evolution of the revisions of the MoU is very well summarized by D. Carvalho Martins in Spanish language (see D. Carvalho Martins, Labour Law in Portugal..., p. 71-72).

${ }_{56}$ According to the MoU, "Reforms in labour and social security legislation will be implemented after consultation of social partners, taking into account possible constitutional implications, and in respect of EU Directives and Core Labour Standards" (MoU, p. 21). 
government debt-to GDP ratio on a downward path as of 2013; (iii) maintaining of fiscal consolidation over the medium term up to a balanced budgetary position, notably by containing expenditure growth; and (iv) supporting competitiveness by means of a budget-neutral adjustment of the tax structure. ${ }^{57}$

Regarding the specific subjects on social security, the original version of the $\mathrm{MoU}^{58}$ provided several relevant and impacting proposals. Hence, it should be mentioned the following:

a) reduction of pensions higher than $€ 1.500,00$;

b) the freeze of pensions updates;

c) reform of the unemployment insurance.

In agreement with the MoU, the reduction of pensions above $€ 1.500,00$ should have been made according to the progressive rates applied to the wages of the public sector as of January $2011 .^{59}$ The expectation with this measure was to save directly at least 445 million euros. On the other hand, the freeze of pensions also implied the suspension of the indexation of the pension indexation rules. Yet, the lowest pensions were except form the same rule. ${ }^{60}$ Finally, regarding the reform of the unemployment insurance, the MoU was expecting to promote saving of 150 million euros in a medium term. ${ }^{61}$ In fact, the revision of the unemployment insurance had the goal of reducing "the risk of long-term unemployment while strengthening social safety nets". ${ }^{2}$ This was a key point of the MoU that was supposed to promote an effective reform in the Portuguese employment protection legislation in order to tackle the labour market segmentation, foster job creation, and ease the transition of workers across occupations, firms, and sectors. By these reason, the Portuguese government was embraced by the mission of creating a reform plan with a view to reduce the risk of long-term unemployment and strengthen social safety nets resulting from the following ideas: (i) reducing the maximum duration of unemployment insurance benefits to no more than 18 months; ${ }^{63}$ (ii) capping unemployment benefits at 2.5 times the social support index (IAS) and introducing a declining profile of benefits over the unemployment spell after six months of unemployment (a reduction of at least 10\% in the benefit amount); ${ }^{64}$ (iii) reducing the necessary contributory period to access unemployment insurance from 15 to 12 months; and (iv) presenting a proposal for extending eligibility to unemployment insurance to

57 See MoU's point 1.

58 The original version of the MoU was closed at $17^{\text {th }}$ May of 2011.

59 See MoU's point 1.11.

60 See MoU's point 1.12 .

61 See MoU's point 1.13 .

62 See MoU's p. 21 with the objectives regarding the Labour Market intervention.

63 The reform was not supposed to concern those that were at the time unemployed and, also, was not supposed to reduce accrued-to-date rights of employees.

64 The reform did concern those becoming unemployed after the reform. 
clearly-defined categories of self-employed workers providing their services to a single firm on a regular basis. ${ }^{65}$

MoU's second version ${ }^{66}$ intensified these limitations to another level. In fact, several additions were made through the negotiations between the Portuguese government and Troika. Regarding social security, it's important to point out the following additions:

a) Suspension of the Christmas and vacations bonus for all retired citizens with pensions higher than $€ 1.000,00$.

b) Suspension of one of these bonus for retired people with pension from $€ 485,00^{67}$ and $€ 1.000,00$.

c) Freezing of the pensions lower than $€ 485,00$.

In this scenario, the consequences of the austerity reached to almost all the retirement pensions, when they were supposed to affect only some of highest pensions paid. Even the pensions lower than the national minimum wage started to become suspended. So, at this point, there was an intensification of the debate about the austerity measures due to the fact of all the population being affected.

A third version of $\mathrm{MoU}^{68}$ was closed and provided a reform on these aspects:

a) Reduction of pension expenditure in gross terms in 2012 by at least 1,140 million euros by: (i) suspending the 13th and 14th monthly payments for those pensioners with monthly pension benefits of $€ 1.100,00$ or more, (ii) suspending on average and in a progressive way the equivalent of one of those monthly benefits for those with monthly pension benefits between $€ 600,00$ and $€ 1.100,00$. The pensions of those receiving benefits below $€ 600,00$ would be frozen and the lowest pensions would be marginally increased. In case a pensioner that received more than one pension, the consolidated pension income would be considered for the application of the thresholds defined here. These rules were supposed to be applied to subventions or subsidies paid by the government that take the nature of pensions even if designed otherwise.

b) Reduction of cash social transfers (other than pensions) by at least 180 million euros by tightening eligibility criteria and decreasing average benefits in selected cases.

A fifth review of $\mathrm{MoU}^{69}$ promoted the "acceleration the convergence of the system of social protection for staff that are in the Regime de Proteção Social Convergente (RPSC)

${ }_{65}$ The government's proposal was supposed to take into account the risks of possible abuses and contained an assessment of the fiscal impact of extending benefits under several scenarios concerning eligibility criteria (namely the involuntary character of unemployment) and requirements for increased social security contributions for firms making use of these arrangements.

${ }^{66}$ The second version of the MoU was the result of a revision closed at $9^{\text {th }}$ December of 2011. David Carvalho Martins points out that in this version it were promoted several goals that are much more demanding on the reduction of pensions (see D. Carvalho Martins, Enseñanzas de la experiencia...).

67 It's important to mention that $€ 485,00$ was at that time the Portuguese minimum wage.

68 The second revision of the original version was closed in $15^{\text {th }}$ March of 2012.

${ }^{69}$ This version was published in 14 October 2012. 
to the rules of Regime Geral de Segurança Social". Finally, a seventh review was closed by the parties in 25 January 2013. According to this review, increasing the statutory retirement age by changes to the sustainability factor and introducing a progressive sustainability contribution was one of the most impacting measures. Also, it was suggested the creation of a new extraordinary contribution for retirees.

During the intervention of the so-called Troika in Portugal, many changes where promoted in several realities. The Portuguese government was accused of being a Troika's "best student". This "fame" started when the government tried to go further then the $\mathrm{MoU}$ or tried to adjust the cons that resulted from the Constitutional Court's decisions. In light of this government's position, it started a high tension in the Portuguese society, where the Constitutional assumed a leading role that became internationally notorious.

\section{Assessment of the future of social security rights in lights of the Constitution}

Within this context of crisis where constant changes were provided by the MoU and accomplished by the Portuguese Government, some social security rights where in distress. First, we must emphasise, again, the intergenerational debate brought by these proposed changes. Second, a new actor assumed a position of protection of the Constitution's social rights - the Constitutional Court. The Court's intervention was more active regarding budget laws "designed" in respect of the MoU.

Maybe by the first time in last years, the Constitutional Court assumed an intense position in confrontation with most of the changes approved by the government in respect of the MoU. ${ }^{70}$ The impact of this Court's positioning went outside Portuguese borders as an example of resistance against austerity. ${ }^{11}$ So, the Judges were, actually, a kind of lawmakers during this period through several judgements. ${ }^{72}$ In the following cases, the Court was not judging directly the MoU, but the law making in respect of the agreement or, sometimes, that went even further.

The Judgment no. 353/2012 analysed the suspension of the Christmas and vacation bonus for all retired citizens introduced in the ordinary legislation. This way, the Court decided that the regular payments to these citizens, including Christmas and vacation bonus are part of the pension. For this reason, this suspension was considered unconstitutional by the Court. In fact, according to the Court's Judgement, this austerity measure was in violation of the principle of equality on the distribution of public expenditure. ${ }^{73} \mathrm{~A}$ second

70 Or sometimes when going further then the MoU.

71 See R. Cisotta, D. Gallo, The Portuguese Constitutional Court Case Law on Austerity Measures: A Reappraisal, Working paper 4/2014, LUISS Academy.

72 In the same sense, R. Cisotta, D. Gallo, The Portuguese Constitutional Court..., p. 1.

73 Regarding this judgment, Gonçalo de Almeida Ribeiro argues that "The first argument was of the negative sort: it rejected the Government's claim that there are reasons of fairness to place a heavier burden on civil servants than income-earners generally since the former's salaries are on average higher 
argument was pointed out by the Court, where it affirmed that the only legitimate reason to favor pay cuts over taxation is the pragmatic concern with the differential fiscal and economic effects of the two policies. Even though the strong environment of crisis, the Court argued that the new cuts exceeded the margin of distributional difference that it could be justifiable in this case. The Court admitted, however, that in some cases it could be reasonable to have civil servants bear a heavier burden than private sector employees, but the it decided that in this situation things went too far. David Carvalho Martins underlines the pedagogic character of this judgment, since, as we will see, it was coherent with the following decisions. ${ }^{74}$

In the following year, the Court continued its intervention with Judgement no. 187/2013. Part of this judgment was in respect of the partial suspension of Christmas and vacation bonus by using an extraordinary solidarity contribution in order to finance the social security system. In this case, the Court accepted that a special contribution could be according to the Constitution due to the extraordinary crisis in Portugal. Nevertheless, it was assumed that retired citizens had a different position than workers from the public sector, since they are in a passive position. About this judgement, Gonçalo Almeida Ribeiro mentioned that

the Court again held the pay cuts unconstitutional, repeating the 2012 argument that they were excessive, but casting it in a diachronic setting: as time progresses, argued the Court, the reason to target public sector employees grows weaker since the cumulative effect of three years of pay cuts increases the weight of the burden placed specifically on their shoulders while, on the other hand, the Government had plenty of time to find workable alternatives to reduce public expenditure. ${ }^{75}$

Also in 2013, the Constitutional Court provided another judgment about the austerity measures in respect of the MoU - Judgment no. 862/2013. In this constitutional review, the Court analysed the pension reduction paid by the social security system to public sector workers. The Court maintained the same position, this time based in the principle of confidence, since it aimed to protect the economic security of the older citizens.

Finally, in the judgement no. 413/2014 the Court decided about the following relevant subjects:

a) suspension of the pension complements paid by Caixa Geral de Aposentações or another social security system in the public corporate sector with negative years;

and they benefit from a much more favorable regime of dismissal than private sector employees, reflected in the rate of unemployment. The Court reasoned that it is impossible to compare salaries in the two sectors, given job description and level of instruction differentials, and that it makes no sense to invoke the unemployment rate, since the alternative policies under discussion pay cuts and taxes target employed workers" (see G. de Almeida Ribeiro, Judicial Activism Against Austerity in Portugal, International Journal of Constitutional Law Blog, Dec. 3, 2013, available at: http://www.iconnectblog.com/2013/12/judicialactivism-against-austerity-in-portugal/).

${ }^{74}$ See D. Carvalho Martins, Enseñanzas de la experiencia...., p. 72. Catarina Santos Botelho interpreted the Court's judgment in the same way (see C. Santos Botelho, 40 Anos De Direitos Sociais..., p. 214).

75 See G. de Almeida Ribeiro, Judicial Activism... 
b) the contribution of $5 \%$ and $6 \%$ for unemployment and sickness benefits;

c) new regime of survival pension to compensate families for the death of the beneficiary.

First, regarding the suspension of complements, the Court decided that the measure was not in breach of the Constitution because a public company with negative results could not promote legitim aspirations. Therefore, the principle of confidence was not endangered. Second, about the new contribution on unemployment and sickness benefits, the Court's decided as unconstitutional by breaching the principle of proportionality. According to the judgment, citizens with these benefits were depending on them to survive so, the measure was not indispensable. Third, in respect of the new regime for survival pension, it was the court's decision that even though the principle of confidence was not endangered, the measure was unconstitutional because affected part of the most vulnerable population.

Finally, we should make a reference to judgements no. 572/2014 and no. 575/2014. In the first one, the Court's decided about an extraordinary solidarity contribution. So, resulted from the judgement that the measure was according with the Constitution because it was exceptional and exceptional and was important to finance the social security system in a time of economic crisis. On the other hand, judgement no. 575/2014 had a relevant debate about the society's solidarity between generations. Here it was in analysis a sustainability contribution paid by pensions from social security, Caixa Geral de Aposentações and Lawyer and Solicitor's welfare system. This was a definitive measure that aimed to replace the temporary ones. The Court decided that this contribution was unconstitutional because promoted the definitive reduction of these pensions endangering the "contract between generations" where each one has the expectation of being supported by younger generations. Therefore, for the Court the measure breached the principle of confidence. ${ }^{76}$

So, the actions of the Constitutional Court in Portuguese crisis urged the debate about its role in the law-making process. Roberto Cisotta and Daniele Gallo pointed out that "it may be inferred that lying at the core of Tribunal's overall approach in its jurisprudence on the social side effects of the economic crisis is the issue of the relationship between the legislature and the judiciary, with regard to the legitimacy of measures which are the result of redistributive policy decisions democratically taken by the parliament".77 Therefore, these authors interpreted the Court's decisions relied on the principle of equality in order to urge the law maker "to better exercise the competences and powers its seems to have gave up in favour of international and European constraints".78 This

${ }^{76}$ However, the contract between generations have two parties. The Court usually takes into account the present beneficiaries and not the future ones. In a society where the population is decreasing and becoming older as a hole, this subject must be rethink. In fact, indicators about ageing shows us that in each 100 young citizens, there are $148,7 \%$ elderly citizens (source: prodata website that can be consulted in https://www.pordata.pt/Site/MicroPage.aspx?DatabaseName=Portugal\&MicroName=Indicadores $+\mathrm{d}$ e+envelhecimento\&MicroURL=526\&).

77 See R. Cisotta, D. Gallo, The Portuguese Constitutional Court..., p. 10.

78 See ibidem, p. 10. 
way, by recognizing the "approach of taken by the Tribunal seems to exceed national boundaries and became a tool of confrontation and fertilization amongst constitutional courts in the wake of growing phenomenon of horizontal between national judges", ${ }^{\prime 9}$ Roberto Cisotta and Danielle Gallo accept this Court's role as an "agent of change or guardian" of constitutional rights when they are at risk, even when before international commitments..$^{80}$ Andreas Dimopoulos ${ }^{81}$ defended in 2013 while researching the balance of constitutional review that the Portuguese Court was "taking a robust stance against austerity measures, and perhaps overstepping its constitutional role by suggesting to the legislator that different measures should be adopted in order to tackle the economic crisis, rather than being deferential to political choices in a time of grave economic crisis". ${ }^{82}$ Still, this author accepted the Court's decision due to the uncertainty of the austerity measures before the importance, for example, of salary.

Catarina Santos Botelho accepts that after the Second WW, the Constitutions became more political, but not party related. ${ }^{83}$ Still, the author believe that a strict economic interpretation could endanger the constitutional interpretation of crisis.

However, this point of view it's not unanimous. For example, Gonçalo Almeida Ribeiro promotes the following debate: "Now why would a democratic constitution weaken a majority directly accountable before the demos $\bigotimes$ the majority in Parliament $₫$ to empower a majority of unelected and unaccountable judges? Why should democracy give way to juristocracy?". ${ }^{44}$ So, these questions urge another autonomous debate about the limits of the Constitutional Court intervention. Also, some authors tried to analyse the judges' behaviour could be framed as "activism". ${ }^{5}$

We believe that the Constitutional Court should have always a key role in the protection of social rights. ${ }^{86}$ In the recent Portuguese crisis, judges assumed this position in direct confrontation not only against the government, but also against the external

79 See ibidem, p. 10.

80 See ibidem, p. 11.

81 See ibidem, p. 10.

82 See A. Dimopoulos, Constitutional Review of Austerity Measures in the Eurozone Crisis, 2013, p. 9, available at SSRN: https://ssrn.com/abstract=2320234 orhttp://dx.doi.org/10.2139/ssrn.2320234 and A. Dimopoulos, PIGS and Pearls: State of Economic Emergency, Right to Resistance and Constitutional Review in the Context of the Eurozone Crisis (September 30, 2013), Vienna Journal on International Constitutional Law 2013, 4, available at SSRN:https://ssrn.com/abstract=2333462.

83 See C. Santos Botelho, Os direitos sociais..., p. 290-291.

84 See ibidem.

85 See S. Coroado, N.M. Garoupa, P.C. Magalhães, Judicial Behavior under Austerity: An Empirical Analysis of Behavioral Changes in the Portuguese Constitutional Court, 2002-2016 (March 1, 2017), Journal of Law and Courts, Forthcoming; Texas A\&M University School of Law Legal Studies Research Paper No. 17-32, available at SSRN: https://ssrn.com/abstract=2928196. These authors concluded that "the judicial behavior of austerity policies exhibits much less exceptional patterns than often argued".

${ }^{86}$ Regarding the principle of freedom of association, we defended that the Constitutional Court had shown "a demonstrable major role in ensuring the freedom of association set by the Portuguese Constitution" (see D. Abrunhosa e Sousa, Portuguese Labor Austerity Measures and the Principle of Freedom of Association, International Labor Rights Case Law 2016, 2, Brill, p. 136-141). 
entities represented by Troika. Nevertheless, the intergenerational conflict on social rights was partially aroused by the Court's decisions. Also, we cannot forget that being the Court a "political” institution, this fact can stimulate some doubts about the judges' interventions as criticized by Gonçalo Almeida Ribeiro.

Regarding the future of social security rights in light of the Portuguese Constitution, despite all this active intervention of the Court, it seems that new problems are arising. The "contract between generations" that provided social rights in the system could be affected by the demographic changes. In contrast with the reality some years ago, presently the younger generations seem not to be enough to support that "contract". So, the Constitutional Court should contribute for the future solution and not just for the increment of the problem. The pedagogic approach in some judgments is probably a good example on the Court's role in response to the future.

\section{Conclusions}

The Portuguese Constitution is very well "equipped" with a wide range of social rights through its own text that enables it to face demanding challenges through different economic cycles. ${ }^{87}$ However, in times of crisis, the Constitution is always at risk since social rights cannot be maintained without high costs. This way, when a State needs to cut-off expenses to recover from the deficit, usually it's very tempting to reduce or temporarily suspend social rights in general. Therefore, the recent crisis launched the debate about the protection of social rights in the countries intervened by the Troika.

If we take into account what happened in Portugal, it's easy to understand the role of the Constitutional Court to protect these rights, avoiding that the economic situation could be used as an argument to promote all the changes included in the MoU. So, if the MoU did not assume the form of international treaty, the measures imposed needed to respect the Portuguese Constitution, since they were materialized through ordinary law. In fact, social rights could not be dependent on the constant crisis, because if that happens the citizens' principle of confidence on the State would be endangered.

Nevertheless, although we believe that social rights should not be dependent on economic cycles, it's important to underline that it's important to rethink the future of some rights that we take for granted. As a matter of fact, the society is developing and profound changes are happening gradually. The growth of the elderly and the decrease of young workers in Portugal is becoming a critical problem that could promote faster and more persistent negative cycles. That said, declarations of unconstitutionality by the Court probably is no longer the solution. The solutions pass through rethinking social rights in times that the "contract between generations" is at risk due to demographic

87 C. Santos Botelho reminds us that the Portuguese Constitution is internationally recognize for hosting a catalogue of social rights higher than most of the other countries in EU (see C. Santos Botelho, 40 Anos De Direitos Sociais..., p. 208). 
changes. Only this way is possible to ensure a vast number a social rights to all and through a longer period of time.

\section{References}

Abrunhosa e Sousa D., Portuguese Labor Austerity Measures and the Principle of Freedom of Association, International Labor Rights Case Law 2016, 2, 2016, Brill.

Carvalho Martins D., Enseñanzas de la experiencia portuguesa, Compatibilidad de prestaciones de Seguridad Social con Trabajo - directed by Carmen Sanchez Trigueros, Aranzadi 2016.

Carvalho Martins D., Labour Law in Portugal between 2011 and 2014, Labour Law and Social Security Law at the Crossroads - Focused on International Labour Law Standards and Social Reforms, M. Stefko (ed.), Charles University in Prague, Faculty of Law, 2016.

Cisotta R., Gallo D., The Portuguese Constitutional Court Case Law on Austerity Measures: A Reappraisal, Working paper 4/2014, LUISS Academy.

Conceição A., Segurança Social, $9^{\text {th }}$ ed. Almedina 2014.

Coroado S., Garoupa N.M., Magalhães P.C., Judicial Behavior under Austerity: An Empirical Analysis of Behavioral Changes in the Portuguese Constitutional Court, 2002-2016 (March 1, 2017), Journal of Law and Courts, Forthcoming; Texas A\&M University School of Law Legal Studies Research Paper No. 17-32, available at SSRN: https://ssrn.com/abstract=2928196.

de Almeida Ribeiro G., Judicial Activism Against Austerity in Portugal, International Journal of Constitutional Law Blog, Dec. 3, 2013, available at: http://www.iconnectblog.com/2013/12/ judicial-activism-against-austerity-in-portugal/.

de Melo Alexandrino J., Direitos Fundamentais - Introdução Geral, Principia 2007.

Dimopoulos A., Constitutional Review of Austerity Measures in the Eurozone Crisis, 2013, p. 9, available at SSRN: https://ssrn.com/abstract=2320234 orhttp://dx.doi.org/10.2139/ ssrn.2320234.

Dimopoulos A., PIGS and Pearls: State of Economic Emergency, Right to Resistance and Constitutional Review in the Context of the Eurozone Crisis (September 30, 2013), Vienna Journal on International Constitutional Law 2013, 4, available at SSRN:https://ssrn.com/ abstract $=2333462$.

Miranda J., Manual de Direito Constitucional, Vol. IV, $5^{\text {th }}$ ed., Coimbra 2012.

Miranda J., Medeiros R., Constituição Portuguesa Anotada, Vol. I, Coimbra 2005.

Santos Botelho C., 40 Anos De Direitos Sociais - Uma Reflexão Sobre O Papel Dos Direitos Fundamentais Sociais No Século XXI [40 Years of Fundamental Social Rights - A Reflection on the Role of Fundamental Social Rights in the 21st Century], Julgar 2016, 29, p. 197-216, available at SSRN: https://ssrn.com/abstract=2912278.

Santos Botelho C., Os direitos sociais num contexto de austeridade: um elogio fúnebre ao princípio da proibição do retrocesso social? [Social Rights in a Context of Austerity: An Eulogy to the Principle of the Prohibition of Social Retrogression?], Revista da Ordem dos Advogados 2015, I/II, p. 259-294. Available at SSRN: https://ssrn.com/abstract=2911142.

Sérvulo Correia J.M., Teoria da Segurança Social, Lisbon 1965-1966. 
Vieira de Andrade J., O Direito ao mínimo de existência condigna, Jurisprudência Constitucional 2004.

Vieira de Andrade J., Os Direitos Fundamentais na Constituição Portuguesa de 1976, $2^{\text {nd }}$ ed., Almedina 2001. 